\title{
PENYELESAIAN PERSELISIHAN HUBUNGAN INDUSTRIAL MENURUT UNDANG-UNDANG KETENAGAKERJAAN
}

\author{
Oleh : \\ Ir. I Ketut Simpen, MH \\ Herry Indiyah Wismani, SH, MH
}

\author{
Program Studi, Fakultas Hukum Universitas Mahendradatta \\ Jl. Ken Arok No. 12 , Peguyangan Denpasar Utara, Bali 80115. \\ (simpenketut88@gmail.com)
}

\begin{abstract}
Abstrak, Perselisihan atau sengketa senantiasa dimungkinkan terjadi dalam setiap hubungan antar manusia termasuk perselisihan dalam hubungan kerja. Perselisihan hubungan industrial biasanya terjadi antara pekerja/ buruh dan pengusaha/ majikan atau antara organisasi pekerja/ organisasi buruh dengan organisasi perusahaan/ organisasi majikan. Perselisihan hubungan industrial dapat dibagi menjadi dua, yaitu : a) Perselisihan hubungan industrial menurut sifatnya, yang terdiri atas : Perselisihan hubungan industrial kolektif, dan Perselisihan hubungan industrial perorangan b) Perselisihan Hubungan Industrial menurut jenisnya, yang terdiri dari Perselisihan hak dan Perselisihan Kepentingan. Penelitian ini merupakan penelitian hukum yang bersifat normatif yakni suatu penelitian yang terutama menganalisis ketentuan-ketentuan hukum positif maupun asas-asas hukum, dengan melakukan penjelasan secara sistematis. Adapun permasalahan yang dikaji yakni bagaimanakah Mekanisme Penyelesaian Perselisihan Hubungan Industrial menurut Undang-undang Ketenagakerjaan. Mekanisme penyelesaian perselisihan hubungan industian dilakukan dengan 2 cara yaitu melaui jalur non litigasi yang dilakuakn dengan cara bipartid (masing-masing pihak yang berselisih) dan tripartid (mediasi, negosiasi, dan konsilidasi)dan melalui jalur litigasi (jalur pengadilan yakni Pengandilan Hubungan industrial.
\end{abstract}

Kata kunci : Hubungaan kerja, Perselisihan, penyelesaian

Abstract, Disputes or disputes are always possible in every human relationship including disputes in work relations. Industrial relations disputes usually occur between workers / employers and employers or between workers 'organizations / labor organizations and company organizations / employers' organizations. Industrial relations disputes can be divided into two, namely: a) Industrial relations disputes according to their nature, which consist of: Collective industrial relations disputes, and individual industrial relations disputes b) Industrial Relations Disputes according to their type, which consist of Rights Disputes and Interest Disputes. This research is a normative legal research that is a study that mainly analyzes the provisions of positive law and the principles of law, by carrying out systematic explanations. The problems studied are how is the Industrial Relations Dispute Resolution Mechanism according to the Labor Law. The industrial relations dispute resolution mechanism is carried out in two ways, namely through a non-litigation path that is carried out by bipartid (each disputing party) and tripartid (mediation, negotiation, and consolidation) and through litigation channels (court lines namely Industrial Relations Control.

Keywords: Work relations, Disputes, settlement

\subsection{Latar Belakang}

Perselisihan atau sengketa senantiasa dimungkinkan terjadi dalam setiap hubungan antar manusia, bahkan mengingat subyek hukumpun telah lama mengenal badan hukum maka para pihak yang terlibat didalamnya semakin banyak. Dengan semakin kompleksnya corak kehidupan masyarakat maka ruang lingkup kejadian ataupun peristiwa perselisihan semakin luas, diantaranya yang sering menyedot perhatian adalah perselisihan hubungan industrial. Perselisihan hubungan 


\section{Raad Kertha, Vol. 02, No. 02 Agustus 2019 - Januari 2020}

industrial biasanya terjadi antara pekerja/ buruh dan pengusaha/ majikan atau antara organisasi pekerja/ organisasi buruh dengan organisasi perusahaan/ organisasi majikan. Dari sekian banyak kejadian atau peristiwa konflik atau perselisihan yang terpenting adalah bagaimana solusi untuk penyelesaiannya agar betul-betul obyektif dan adil. (Lalu Husni : $2004:$ 10). Badan hukum di Indonesia terdiri dari

i) Perseroan Terbatas (PT),

ii) Badan Usaha Milik Negara (BUMN),

iii) Perusahaan Umum (PERUM),

iv) Perusahaan Jawatan (PERJAN),

v) Yayasan, dan Koperasi.

Penyelesaian perselisihan pada dasarnya dapat diselesaikan oleh para pihak sendiri, dan kalau para pihak tidak dapat menyelesaikannya baru diselesaikan dengan hadirnya pihak ketiga, baik yang disediakan oleh negara atau para pihak sendiri. Dalam masyarakat modern yang diwadahi organisasi kekuatan publik berbentuk negara, forum resmi yang disediakan oleh negara untuk penyelesaian sengketa atau perselisihan biasanya adalah lembaga peradilan. Tapi apakah lembaga peradilan tepat guna untuk penyelesaian perselisihan hubungan industrial tentunya menarik untuk dicermati. Peradilan merupakan lembaga penyelesaian perselisihan pada masyarakat modern, yang sebelumnya masyarakat adatpun secara tradisional sebelum mengenal negara dengan lembaga peradilannya, telah punya cara penyelesaian sengketa antar warga, yang biasanya dilaksanakan melalui para tetua adat yang bertindak sebagai fasilitator atau juru damai. Jadi adanya juru damai dalam penyelesaian sengketa bukanlah hal baru bagi masyarakat Indonesia.

Sejalan dengan kebutuhan masyarakat Indonesia pada saat ini untuk penyelesaian perselisihan hubungan industrial secara normatif telah mengalami banyak perubahan, antara lain dengan di undangkannya UndangUndang Nomor 2 Tahun 2004 Tentang Penyelesaian Perselisihan Hubungan Industrial. Diundangkannya Undang-Undang ini dengan latar belakang bahwa Undang-Undang Nomor 22 Tahun 1957 tentang Penyelesaian Perselisihan Perburuhan dan Undang-Undang Nomor 12 Tahun 1964 Tentang Pemutusan Hubungan Kerja di Perusahaan Swasta sudah tidak sesuai lagi dengan kebutuhan masyarakat, sedangkan di era indutrialisasi ini masalah perselisihan hubungan industrial semakin 
meningkat dan kompleks sehingga diperlukan institusi dan mekanisme Penyelesaian Perselisihan Hubungan Industrial yang cepat, tepat, adil, dan murah.

Dengan diundangkannya UndangUndang Nomor 2 Tahun 2004 Tentang Penyelesaian Perselisihan Hubungan Industrial diharapkan hubungan industrial yang harmonis, dinamis, dan berkeadilan sesuai dengan nilainilai Pancasila dapat diwujudkan.

Berdasarkan Undang-Undang Nomor 2 Tahun 2004 Tentang Penyelesaian Perselisihan Hubungan Industrial ini telah ada peradilan khusus yang menangani Penyelesaian Perselisihan Hubungan Industrial, yaitu PHI (Pengadilan Hubungan Industrial). Pengadilan ini bertempat di Renon, Denpasar menjadi satu atap dengan kantor Departemen Tenaga Kerja dan Transmigrasi Provinsi Bali, dibentuk dalam lingkungan Pengadilan Negeri yang berwenang memeriksa, mengadili dan memberi putusan terhadap Perselisihan Hubungan Industrial. Walaupun ada Pengadilan Hubungan Industrial tapi fungsi juru damai (Mediator) untuk berperan dalam Penyelesaian Perselisihan Hubungan Industrial tetap diperlukan.
Perselisihan atau sengketa para pihak biasanya terjadi jika salah satu pihak menghendaki pihak lain untuk berbuat atau tidak berbuat sesuatu, tetapi pihak lainnya menolak untuk berbuat atau berlaku demikian. Begitu juga dalam hubungan industrial, hanya saja ruang lingkupnya sekitar kepentingan pekerja/ buruh, pengusaha, dan pihak pemerintah, karenanya ketiga subyek hukum ini merupakan pilar pendukung suksesnya pelaksanaan hukum ketenagakerjaan termasuk pula untuk suksesnya penyelesaian perselisihan hubungan industrial.

Subjek utama dalam hubungan industrial adalah pekerja/ buruh dengan pengusaha/ majikan, kedua pihak terikat dalam hubungan industrial dikarenakan perjanjian kerja dan/ atau perjanjian kerja bersama. Berdasarkan pandangan struktural fungsional baik pekerja/ buruh maupun pengusaha/ majikan adalah pihak-pihak yang sebenarnya sama-sama mempunyai kepentingan dengan kelangsungan usaha perusahaan. Keuntungan yang diperoleh perusahaan adalah dambaan bersama antara pekerja/buruh juga pengusaha/ majikan. Untuk kepentingan bersama ini secara ideal menghendaki agar ke dua pihak saling memberikan kontribusi optimal untuk 


\section{Raad Kertha, Vol. 02, No. 02 Agustus 2019 - Januari 2020}

produktivitas kegiatan usaha. Karenanya

keserasian hubungan antara mereka menjadi sangat diperlukan, dan hal ini dicerminkan oleh adanya kepuasan para pihak dalam pemenuhan hak dan kewajiban. Apabila terjadi ketidakpuasan, maka akan timbul kegoncangan-kegoncangan yang bermuara pada perselisihan hubungan industrial. Sebagai gejala biasanya pekerja/ buruh tampil dengan berbagai pengaduan atau serangkaian demo atau aksi mogok, untuk reaksinya maka pengusaha/ majikan tidak segan-segan untuk melakukan loc-out atau pemutusan hubungan kerja. Dari pengamatan atas kasus-kasus perselisihan hubungan industrial yang paling banyak kepermukaan adalah kasus PHK (Pemutusan Hubungan Kerja).

Bagi pekerja/ buruh yang umumnya tidak mudah untuk mendapat kerja baru, masalah Pemutusan Hubungan Kerja adalah awal penderitaan panjang. Dari berbagai media sering diperoleh informasi tentang adanya perusahaan-perusahaan yang melakukan rasionalisasi manajemen perusahaan yang merugikan kepentingan pekerja/ buruh, dimana perusahaan perusahaan yang melakukan kebijaksanaan manajemen atau rasionalisasi perusahaan dengan cara pemutusan hubungan kerja masal dengan melepas tanggungjawabnya untuk memenuhi hak-hak pekerja/ buruh terutama hak untuk mendapat pesangon yang memadai. Kebijakan seperti ini diantaranya ada pada kebijakan perusahaan untuk menerapkan sistim "outsourcing" yang nyatanya melepas tanggung jawab suatu perusahaan yang memperkerjakan pekerja/ buruh pada perusahaan lain.

Saat ini pekerja/ buruh umumnya berada dalam posisi yang lemah. Mereka umumnya miskin, dan sulit untuk memperoleh jaminan kerja dengan imbalan penghasilan yang pantas. Sehingga banyak angkatan kerja yang hengkang ke luar negeri untuk menjadi Tenaga Kerja Indonesia walaupun dengan risiko perlindungan keselamatan kerja yang sangat rawan. Kemiskinan melanda sebagian besar pekerja/ buruh di Indonesia, dan hanya beberapa saja pekerja/buruh yang menikmati upah atau penghasilan berkecukupan. Mereka umumnya terdiri dari buruh pabrik, keadaannya sangat memprihatinkan, kadang perut mereka dalam keadaan keroncongan, tidak mampu memenuhi kebutuhan keluarga termasuk untuk beli susu untuk bayinya, tidak mampu menyekolahkan anaknya kejenjang yang lebih tinggi dari SD, walaupun setiap hari tenaganya 
diporsir untuk perusahaan. Sementara disisi lain pengusaha/ majikan dengan modal yang dia miliki, dan dengan latar belakang melimpahnya angkatan kerja yang berarti peluang begitu mudahnya untuk mendapatkan pekerja/ buruh baru menjadikannya begitu besar dan begitu dominan dihadapkan pada keadaan pekerja/ buruh. Dalam kondisi seperti ini aturan hukum harus punya kemampuan untuk terwujudnya keseimbangan hak dan kewajiban antara pengusaha/ majikan dengan pekerja/ buruh. Liberalisasi sepertinya telah membudaya di seluruh dunia, dan telah masuk di Indonesia semenjak pemerintahan Orde Baru berlanjut hingga saat ini. Di bidang ekonomi liberalisasi ada juga segi positifnya untuk pertumbuhan ekonomi, tapi disisi lain menimbulkan dampak yang tidak menguntungkan bagi kelompok ekonomi lemah yang cenderung semakin termarjinalkan.

Hal ini ditandai semakin kompetitifnya lapangan kerja serta melemahnya perlindungan hukum terhadap pekerja atau buruh sebagai kelompok ekonomi lemah. Melemahnya perlindungan hukum terhadap pekerja/ buruh tidak hanya dalam hal pelaksanaan hukum materil, tapi juga dirasakan dalam hal pelaksanaan hukum formal. Dari segi hukum materiil, walaupun telah diundangkan UndangUndang Nomor 13 Tahun 2003 Tentang Ketenagakerjaan tapi posisi pekerja/ buruh terutama pekerja/ buruh kualifikasi non skill seperti para tenaga operator/ pekerja pabrik masih sangat lemah perlindungan hukumnya. Sedangkan pekerja/ buruh non skill ini bagian terbesar dari komunitas pekerja/ buruh di Indonesia. Begitu juga halnya dari segi hukum acara (hukum formal), walaupun telah diundangkan Undang-Undang Nomor 2 Tahun 2004 Tentang Penyelesaian Perselisihan Hubungan Industrial menggantikan UndangUndang Nomor 22 Tahun 1957 tentang Penyelesaian Perselisihan Perburuhan nyatanya pihak pekerja/ buruh masih belum dapat memenuhi harapannya untuk menikmati penyelesaian perselisihan ketenagakerjaan/ perburuhan secara cepat, tepat, adil dan murah. Salah satu masalah dari hukum formal yang mengatur Penyelesaian Perselisihan Industrial adalah disebabkan karena Hukum Acara yang berlaku di PHI (Pengadilan Hubungan Industrial) adalah Hukum Acara yang berlaku di Peradilan Umum, yang rumit dan panjang. Biasanya untuk proses perkara di tingkat Pengadilan Negeri setidaknya pekerja/ buruh yang berperkara harus bersidang antara 8 
hingga 10 kali . Belum lagi dengan biaya lainnya seperti untuk transportasi ke tempat persidangan di PHI yang hanya ada di kota provinsi. Sejalan dengan semakin meluasnya opini masyarakat tentang pro dan kontranya terhadap eksistensi dan aktifitas kinerja PHI (Pengadilan Hubungn Industrial) dan untuk antisipasi agar pekerja/ buruh tidak menjadi pihak yang dirugikan dan mendapat peluang untuk menikmati hasil pembangunan secara layak sesuai proporsinya dalam proses pembangunan perlu kiranya langkah-langkah kongkrit pembenahan tatanan hukum khususnya yang mengatur hubungan industrial. permasalahan dalam jurnal ini bagaimanakah Mekanisme Penyelesaian Perselisihan Hubungan Industrial menurut Undang-undang Ketenagakerjaan?

\subsection{Tujuan Penelitan}

\subsubsection{Tujuan Umum}

Penelitian ini dimaksudkan sebagai sumbangan pemikiran konsepsional tentang kajian Penyelesaian Perselisihan Hubungan Industrial

\subsubsection{Tujuan Khusus}

1. Untuk dapat mengetahui dan memahami mekanisme penyelesaian Perselisihan
Hubungan Industria menurut Undangundang Ketenagakerjaan

2. Untuk dapat mengetahui dan memahami mengenai Upaya Pemerintah dalam mengatasi terjadinya Perselisihan Hubungan Industrial?

\subsection{Manfaat Penelitian}

\subsubsection{Manfaat Teoritis}

Hasil penelitian ini diharapkan bermanfaat sebagai sumbangan pemikiran dan sebagai bahan bacaan bagi pihak-pihak yang memerlukannya mengenai Penyelesaian Perselisihan Hubungan Industrial .

\subsubsection{Manfaat Praktis}

Menambah wawasan pengetahuan penulis dan untuk melengkapi salah satu syarat akademik dalam menyelesaikan studi di Magister Ilmu Hukum Pemerintahan di Universitas Mahendradatta.

\subsection{Metode Penelitian}

Agar suatu tulisan yang berdasarkan penelitian dapat dikatakan memenuhi kreteria sebagai karya ilmiah, maka diperlukan suatu metode. Penelitian ini merupakan penelitian hukum yang bersifat normatif (dogmatik), yakni suatu penelitian yang terutama menganalisis ketentuan-ketentuan hukum positif maupun asas-asas hukum, dengan 
melakukan penjelasan secara sistematis. Bahan hukum yang digunakan adalah : a) Bahan hukum primer dalam bentuk ; 1) UndangUndang tentang Ketenagakerjaan, UndangUndang Nomor 13 Tahun 2003, (Lembaran Negara Republik Indonesia Tahun 2003 Nomor 39, Tambahan Lembaran Negara Republik Indonesia Tahun 2003 Nomor 4279). 2) Undang-Undang Nomor 2 Tahun 2004 Tentang Penyelesaian Perselisihan Hubungan Industrial. b) Bahan hukum sekunder meliputi bahan yang mendukung bahan hukum primer seperti bukubuku hukum, putusan Pengadilan dan lain-lain.

c) Bahan hukum tersier yaitu "bahan hukum penunjang yang memberi petunjuk dan penjelasan terhadap bahan hukum primer. Bahan hukum sekunder, seperti kamus umum, kamus hukum, majalah/jurnal atau surat kabar sepanjang memuat informasi yang relevan dengan materi penelitian ini". (Soeryono Soekanto dan Sri Mamudji, 1985: 23). Pengumpulan bahan hukum dilakukan melalui studi Kepustakaan (library research) dikumpulkan melalui studi literatur, dokumen dan dengan mempelajari ketentuan perundangundangan tentang tindak Penyelesaian Perselisihan Perburuhan maupun Undangundang yang berhubungan dengan
Ketenagakerjaan. Setelah semua bahan hokum sekunder diperoleh melalui studi kepustakaan (library research) maka dilakukan pemeriksaan dan evaluasi untuk mengetahui validitasnya, kemudian bahn hukum dikelompokkan yang sejenis. Terhadap bahan hukum yang sifatnya kualitatif ditafsirkan secara yuridis, logis, sistematis dengan menggunakan metode deduktif dan induktif. Metode induktif maksudnya menarik dari generalisasi yang berkembang dalam praktek terjadinya perselisihan dalam ketenaga kerjaan. Metode deduktif maksudnya melihat suatu peraturanperaturan yang berlaku dalam proses Penyelesaian Perselisihan Hubungan Industrial . Dengan menggunakan metode deduktif dan induktif ini, maka akan diperoleh persesuaian tentang bagaimana sebenarnya hakim menggunakan kewenangannya dalam penerapan hukum dalam Penyelesaian Perselisihan Hubungan Industrial. Dari hasil pembahasan dan analisis ini diharapkan dan diperoleh kesimpulan yang memberikan jawaban atas permasalahan yang diteliti.

\subsection{Kajian Pustaka}

Sejak pemerintahan orde baru, pemerintah telah bertekad untuk melaksanakan Pancasila dan UUD 1945 
secara murni dan konsekuen dalam setiap aspek kehidupan bermasyarakat, berbangsa dan bernegara. Salah satu aspek tersebut adalah tata pergaulan atau kehidupan di tempat bekerja/perusahaan yang lazim disebut hubungan industrial, karena itu aspek ini harus ditata sesuai dengan jiwa dan semangat Pancasila dan UUD 1945. Sebelum lebih jauh menguraikan mengenai konsepsi hubungan industrial, maka akan diuraikan mengenai beberapa bentuk hubungan industrial yang dikenal, yakni :

1. Hubungan Industrial berdasatkan demokrasi liberal

Hubungan industri ini berlandaskan pada falsafah individualisme dan liberalisme yang dianut negara-negara industri barat pada umumnya. Ciri-ciri hubungan industrial atas dasar demokrasi liberal adalah :

a. Pekerja dan pengusaha mempunyai kepentingan yang berbeda, yakni kepentingan pekerja untuk mendapatkan upah yang sebesar-besarnya sedangkan pengusaha untuk mencapai keuntungan yang setinggi-tingginya.

b. Perbedaan pendapat diselesaikan dengan adu kekuatan buruh dengan senjata mogoknya sedangkan pengusaha menutup perusahaannya (lock out).

c. Pekerja sebagai makhluk pribadi sosial.

2. hubungan Industrial atas dasar perjuangan Klas (Class Straggle)

Hubungan industrial ini berlandaskan pada falsafah marxisme/komunisme, dengan ciri-ciri sebagai berikut :

a. Berdasarkan pada teori nilai lebih dari Karl Marx yakni dimana pengusaha selalu berusaha agar ada nilai lebih dengan merampas sebagian upah buruh/pekerja.

b. Pekerja dan pengusaha adalah dua pihak yang bertentangan kepentingan karenanya perbedaan pendapat diselesaikan dengan saling menjatuhkan.

3. Hubungan Industrial atas dasar komitmen seumur hidup (life lang employment)

Dari gambaran di atas terlihat bahwa ketiga masyarakat atau bangsa mempunyai corak atau sistem hubungan industrial tersendiri yang berbeda satu dengan yang lainnya sesuai dengan ideologi, politik, ekonomi, sosial an budaya dari bangsa yang bersangkutan. Hubungan Industrial Pancasila adalah sistem hubungan yang terbentuk antara para pelaku dalam proses 
produksi barang dan jasa (pekerja, pengusaha dan pemerintah) yang didasarkan atas nilai-nilai yang merupakan manifestasi dari keseluruhan sila-sila dari Pancasila dan UUD 1945 yang tumbuh dan berkembang di atas kepribadian bangsa dan kebudayaan nasional Indonesia (Sedjun H. Manulang, $1990: 145)$.

Dari penjelasan di atas, jelas bahwa hubungan industrial Pancasila menghendaki agar para pihak yang terlibat di dalamnya melakukan suatu tindakan apapun harus sesuai dengan nilai-nilai Pancasila, atau jelasnya Hubungan Industrial Pancasila adalah hubungan industrial yang dijiwai oleh kelima sila Pancasila yang berbunyi:

1. Suatu hubungan perburuhan yang didasarkan atas asas Ketuhanan Yang Maha Esa, yaitu suatu hubungan perburuhan yang mengakui dan meyakini kerja sebagai pengabdian manusia kepada Tuhan dan sesama manusia;

2. Suatu hubungan perburuhan yang berdasarkan kemanusiaan yang adil dan beradab, maksudnya tidak menganggap buruh sebagai faktor produksi tetapi sebagai manusia pribadi dengan segala harkat dan martabatnya;
3. Suatu hubungan perburuhan yang didalam dirinya mengandung asas yang dapat mendorong ke arah Persatuan Indonesia, dengan tidak membedakan golongan, perbedaan keyakinan, politik, paham, aliran agama, suku maupun kelamin. (F.X. Djumialdji dan Wiwoho Soedjono,1982:111)

Sebagaimana dikemukakan sebelumnya bahwa Perselisihan hubungan industrial (perselisihan perburuhan) ini menurut Hartono Widodo dan Judiantoro (Hartono Widodo dan Judiantoro, 1992 : 25). dapat dibagi menjadi dua, yaitu

1. Perselisihan hubungan industrial menurut sifatnya, yang terdiri atas :

a. Perselisihan hubungan industrial (perburuhan) kolektif, yaitu perselisihan yang terjadi antara pengusaha/majikan dengan serikat pekerja karena tidak adanya kesesuaian paham mengenai hubungan kerja, syarat-syarat kerja dan/atau keadaan perburuhan.

b. Perselisihan hubungan industrial (perburuhan) perorangan, yakni perselisihan antara pekerja yang tidak menjadi anggota salah satu serikat pekerja dengan pengusaha/majikan. 
2. Perselisihan Hubungan Industrial (Perburuhan) menurut jenisnya, yang terdiri dari :

a. Perselisihan hak, yakni pertentangan antara pengusaha/majikan atau perkumpulan pengusaha dengan serikat pekerja karena salah satu pihak dalam perjanjian kerja atau kesepakatan kerja bersama tidak memenuhi daripada perjanjian kerja tersebut atau melanggar ketentuan hukum yang berlaku bagi hubungan kerja. Dengan kata lain tidak ada persesuaian paham dalam hubungan kerja yang mereka sepakati bersama.

b. Perselisihan Kepentingan, yakni pertentangan antara pengusaha/majikan atau kumpulan pengusaha dengan serikat pekerja atau gabungan serikat pekerja sehubungan tidak adanya persesuaian paham mengenai syaratsyarat kerja dan atau keadaan perburuhan.

Menurut Pasal 1 angka 1 UndangUndang Nomor 2 Tahun 2004 tentang Penyelesaian Perselisihan Hubungan Industrial menyebutkan bahwa perselisihan hubungan industial adalah perbedaan pendapat yang mengakibatkan pertentangan antara pengusaha atau gabungan pengusaha dengan pekerja/buruh atau serikat pekerja/serikat buruh karena adanya perselisihan mengenai hak, perselisihan kepentingan, perselisihan pemutusan hubungan kerja dan perselisihan antar serikat pekerja/serikat buruh dalam satu perusahaan.

\subsection{Hasil Dan Pembahasan}

\subsubsection{Penyelesaian Perselisihan Hubungan Industrial}

Berdasarkan Undang Undang Nomor 2 Tahun 2004 tentang Penyelesaian Perselisihan Hubungan Industrial, Perselisihan hubungan industrial adalah perbedaan pendapat yang mengakibatkan pertentangan antara pengusaha atau gabungan pengusaha dengan pekerja/ serikat buruh karena adanya perselisihan mengenai hak, perselisihan kepentingan, perselisihan pemutusan hubungan kerja, dan perselisihan antara serikat pekerja/ serikat buruh dalam satu perusahaan. Ini berarti bahwa bila tidak ada dan atau dapat menghindari terjadinya perbedaan pendapat yang mengakibatkan pertentangan diantara para pihak sehubungan dengan masalah hak, kepentingan, dan masalah pemutusan hubungan kerja, serta masalah perihal serikat pekerja/ serikat buruh dalam satu perusahaan 
maka tidak akan terjadi sengketa atau perselisihan hubungan industrial. Menurut Soepomo, bahwa pada dasarnya hubungan kerja itu meliputi materi-materi yang berkenaan dengan: (1) pembuatan perjanjian kerja karena merupakan titik tolak adanya suatu hubungan kerja; (2) pekerja/ buruh melakukan pekerjaan pada atau di bawah pimpinan pengusaha/ majikan, yang sekaligus merupakan hak majikan atas pekerjaan dari pekerja/ buruh; (3) kewajiban majikan membayar upah kepada pekerja/ buruh yang sekaligus merupakan hak pekerja/ buruh atas upah; (4) berakhirnya hubungan kerja dan; (5) caranya perselisihan antara pihak-pihak yang bersangkutan diselesaikan dengan sebaik-baiknya"(Imam Soepomo : $1975: 6)$.

\subsubsection{Mekanisme penyelesaian} perselisihan hubungan industrian melalui nonlitigasi dan litigasi

\section{Nonlitigasi}

a. Penyelesaiaan Pemutusan Hubungan kerja Pada Tingkat Bipartite.

Pada prinsipnya setiap kehendak atau rencana pemutusan hubungan kerja, harus dirundingkan pengusaha dengan serikat pekerjanya atau dengan pekerjanya sendiri jika pada perusahaan tersebut belum ada serikat pekerjanya sebagai awal penyelesaian.

Ketentuan ini dapat diambil didalam pasal 2 UU. Nomer 12 tahun 1964, yang menyatakan :

Bila telah diadakan segala usaha, pemutusan hubungan kerja tidak dapat dihindari/perusahaan harus merundingkan maksudnya untuk memutuskan hubungan kerja dengan organisasi buruh yang bersangkutan atau buruh dalam hal buruh itu tidak menjadi salah satu organisasi buruh.

Berdasarkan pasal 2 UU No. 12 tahun 1964 diatas,maka sebelum pengusaha melimpahkan masalah PHK ke Kantor Depertemen Tenaga Kerja, hendaknya terlebih dahulu diselesaikan secara musyawarah mufakat dikalangan intern perusahaan atau dalam hal ini melalui lembaga kerja sama Bipartite.

Penyelesaian secara Bipartite ini akan dilakukan melalui musyawarah antara pengusaha dengan pekerjanya dalam usaha menyelesaikan masalah pemutusan hubungan kerja yang bersangkutan. Didalam keputusan Menteri Tanaga Kerja Nomer: Kep 15 A/MEN/1994. Pasal 4 huruf c disebutkan bahwa, setiap perundingan atau musyarawarah tersebut haruslah dibuat 
risalah perundingan dan dilaksanakan sebanyak-banyaknya 3 (tiga) kali dalam jangka 1 (satu) bulan.

Risalah perundingan ini harus dilampirkan oleh pengusaha pada setiap permohonan ijin pemutusan hubungan kerja baik kepada panitia daerah untuk pemutusan hubungan kerja perseorangan maupun kepada Panitia Pusat untuk pemutusan hubungan kerja kolektif dan upaya pemeriksaan ulang oleh panitia pusat melalui Kantor Wilayah Depertemen Tenaga Kerja.

b. Penyelesaiaan Pemutusan Hubungan kerja Pada Tingkat Tripartite.

1. mediasi

Sesuai ketentuan Pasal 1 Angka 1 Undang-Undang Nomor 2 Tahun 2004 tentang Penyelesaian Perselisihan Hubungan Industrial, apabila tidak terjadi kesepakatan antara para pihak bersengketa, sebagai salah satu upaya yang dapat dilakukan para pihak sebelum perkara sampai ke PHI (Pengadilan Hubungan Industrial) dapat digunakan Lembaga Mediasi. Perkara yang ditangani lembaga mediasi adalah perselisihan hak, perselisihan kepentingan, perselisihan PHK (Pemutusan Hubungan Kerja), dan perselisihan antar serikat pekerja atau serikat buruh hanya dalam satu perusahaan. Mediator dalam rangka penyelesaian perkara melakukan mediasi atau menjadi juru damai yang dapat menjadi penengah dalam penyelesaian sengketa hubungan industrial tersebut.

Pengangkatan seorang Mediator haruslah memenuhi persyaratan sebagaimana diatur dalam Pasal 9 Undang-Undang Nomor 2 Tahun 2004, dan minimal berpendidikan S-1. Untuk pengangkatan dan akomodasinya Mediator ditetapkan oleh Menteri Tenaga Kerja.

Sesuai ketentuan Pasal 10 dan 15 UndangUndang Nomor 2 Tahun 2004, Mediator dalam waktu 7 (tujuh) hari setiap menerima pengaduan si pekerja/ buruh, harus telah mempelajari duduk perkara sengketa yang akan dibawa pada pertemuan para pihak yang bersengketa. Proses mediasi sangat cepat, tidak lebih dari 30 hari kerja.

2. Konsiliasi

Undang-Undang Nomor 2 Tahun 2004 memberi peluang pada para pihak untuk menyelesaikan perselisihan hubungan industria melalui lembaga Konsiliasi. Konsiliator diangkat dan diberhentikan oleh Menteri Tenaga Kerja berdasarkan saran organisasi serikat pekerja/ organisasi buruh. Segala 
persyaratan untuk menjadi pejabat Konsiliator diatur dalam Pasal 19 Undang-Undang Nomor

2 Tahun 2004, dimana tugas terpenting dari Konsiliator adalah memanggil para saksi atau para pihak terkait dalam tempo selambatlambatnya 7 (tujuh) hari sejak menerima penyelesaian konsiliator tersebut.

\section{Arbitrase}

Penyelesaian perselisihan melalui arbitrase pada umumnya telah diatur di dalam UndangUndang Nomor 30 Tahun 1999 tentang Arbitrase dan Alternatif Penyelesaian Sengketa, yang berlaku di bidang sengketa perdagangan. Oleh karena itu arbitrase hubungan industrial yang diatur dalam Undang-Undang Nomor 2 Tahun 2004 adalah merupakan pengaturan khusus bagi penyelesaian sengketa di bidang hubungan industrial. Undang-Undang Nomor 2 Tahun 2004 memberi peluang pada para pihak untuk penyelesaian perselisihan hubungan industrial melalui arbitrase adalah sengketa perihal perselisihan kepentingan dan perselisihan antar Serikat Pekerja dan Majikan di dalam suatu perusahaan.

Penyelesaian perselisihan hubungan industrial melalui arbitrase dilakukan atas dasar kesepakatan para pihak, putusan arbitrase bersifat pinal dan tetap, tidak dapat diajukan gugatan ke PHI (Pengadilan Hubungan Industrial), terkecuali bila dalam hal-hal tertentu dapat dilakukan pembatalan ke MA (Mahkamah Agung) RI.

\section{Litigasi}

a. Pengadilan Hubungan Industial

Apabila pada tahap perundingan bipartit gagal dilanjutkan dengan menggunakan jalur tripartid yakni lembaga mediasi atau konsiliasi dalam rangka penyelesaian perselisihan hubungan industrial. Selanjutnya bila tahap perundingan juga mengalami kegagalan untuk penyelesaian perselisihan maka tahapan ketiga adalah pihak berkepentingan mengajukan gugatan ke PHI ( Pengadilan Hubungan Industrial).

Pengadilan Hubungan Industrial adalah Pengadilan Khusus dalam Peradilan Umum yang menangani proses penyelesaian perselisihan industrial. Sebagai konsekuensi logis dari Undang-Undang Nomor 2 Tahun 2004 yang tidak mengatur secara khusus tentang Hukum Acara PHI, dan berdasarkan Pasal 57 undang-undang ini Hukum Acara yang berlaku di lingkungan PHI adalah Hukum Acara Perdata yang berlaku dalam lingkungan Peradilan Umum, artinya secara umum harus 
menggunakan aturan beracara dalam H.I.R atau

Kitab Undang-Undang Hukum Acara Perdata.

Secara umum proses penyelesaian di PHI mulai dari pengajuan gugatan (pembuatan gugatan, pendaftaran, pembacaan), jawaban, replik, duplik, pembuktian (surat, saksi, persangkaan, pengakuan, dan sumpah), kesimpulan/konklusi, putusan perkara, hingga eksekusi putusan adalah mengikuti HIR. Perbedaan hanya dalam hal:

1) biaya yang digratiskan untuk perkara di bawah nilai Rp. 150.000.000,(seratus lima puluh juta rupiah) karena disubsidi pemerintah sebesar Rp. 7.500.000/ setiap perkara;

2) adanya Hakim Ad hoc yang berasal dari usulan serikat buruh dan organisasi majikan.

Penyelesaian Perselisihan Menurut

Undang-Undang Nomor 22 Tahun 1957:

Pada masa masih berlakunya UndangUndang Nomor 22 Tahun 1957, penyelesaian perselisihan hubungan industrial tertumpu pada Panitia (P4D/P4P) walaupun sebetulnya dapat menggunakan Peradilan Umum (Pengadilan Negeri/ Pengadilan Tinggi) dan juga dapat menggunakan Arbitrase Sukarela (Voluntary Arbitration). Saat itu tidak banyak para pihak yang berselisih perihal hubungan industrial menggunakan jasa Pengadilan Negeri/ Pengadilan Tinggi karena sering kali Pengadilan Negeri/ Pengadilan Tinggi menolak perkara dan menyatakan diri tidak berwenang, hal ini disebabkan karena sudah ada Panitia (P4D/ P4P) yang diberi kewenangan oleh hukum untuk menyelesaikan perselisihan perburuhan berdasarkan Undang-Undang Nomor 22 Tahun 1957.

Disisi yang lain Lembaga Arbitrase Sukarela di bidang perburuhan yang diselenggarakan pihak swasta masih belum poluler, karena Arbitrase Sukarela yang dimaksud oleh Undang-Undang Nomor 22 Tahun 1957 hanya diatur oleh 7 (tujuh) pasal saja, sehingga tidak lengkap dan sulit untuk pelaksanaannya. Juga sebelum tahun 1999 tidak ada satu lembaga atau orang perorangan yang berani menyatakan dirinya sebagai arbiter perburuhan. Baru pada tahun 1999 baru ada dan beroperasi apa yang dinamakan AAKI (Asosiasi Arbiter Ketenagakerjaan Indonesia). Lembaga ini diselenggarakan Fakultas Hukum Universitas Indonesia, bekerjasama dengan AAFLI (Association American of Free Labour Institute). Tapi lembaga inipun kurang 
dimanfaatkan oleh para pihak yang

bersengketa.

\subsection{Kesimpulan}

Berdasarkan uraian pembahasan di atas, maka dapat disimpulkan bahwa mekanisme penyelesaian perselisihan hubungan industian dilakukan dengan 2 cara yaitu melaui jalur non litigasi yang dilakuakn dengan cara bipartid (masing-masing pihak yang berselisih) dan tripartid (mediasi, negosiasi, dan konsilidasi)dan melalui jalur litigasi (jalur pengadilan yakni Pengandilan Hubungan industrial.

\section{Daftar Pustaka}

Abdul Rahman Hadi, Hukum Perburuhan di Indonesia, Raja Grafindo Persada, Jakarta, 2005.

Ali, Achmad, Menguak Tabir Hukum, Cetakan Ketiga, Ghalia Indonesia, Bogor, 2011.

Amiruddin, Asikin, H Zainal, "Pengantar Metode Penelitian Hukum", PT. Persada, 2003.

Ardhiwisastara, Yudha Bhakti Ardhiwisastra, Penafsiran dan Konstruksi Hukum, Alumni, Bandung, 2008.

Artadi, I Ketut, "Hukum dalam Persefektif Kebudayaan", Pustaka Bali Post, 2006 ISBN 979-8496-63-9.

Bungin, Burhan, "Analisis Data Penelitian Kualitatif”, Jakarta: PT. RajaGrafindo Persada, 2008.

Bagir Manan, Arogansi MPR, dalam Harian Republik, Rabu, 9 April 2000.

FX. Djumialdji dan Wiwoho Soejono, Perjanjian Perburuhan dan Hubungan Perburuhan Pancasila, Bina Aksara, Jakarta, 1997. Sari Hukum Perburuhan Pemutusan Hubungan Kerja, Bina Aksara, Jakarta, 1997.
D.H.M. Meuwissen, Meuwissen Pengembangan Hukum, Ilmu Hukum, Teori Hukum, dan Filsafat Hukum, terjemahan B. Arief Shidarta, PT. Refika Aditama, Bandung.

Dirjosisworo, Soedjono, "Pengantar Ilmu Hukum", PT RajaGrafindo Persada, Jakarta, Rajawali Press, 2008.

Hamzah, Andi, "Delik-Delik Tertentu(Speciale Delicten) di dalam KUHP”, Sinar Grafika, 2009.

................, "Terminologi Hukum Pidana", Sinar Grafika, 2008.

Hadi, Sutrisno, "Beberapa Penerapan Psychologi Dalam Industri", Balai

G. Karta Sapoetra cs, Hukum Perburuhan di Indonesia Berlandaskan Pancasila, Bina Aksara, Jakarta, 1986.

Hans Kelsen, General Theory of Law and State, Translate by Anders Wedberg, Russel \& Russel, New York, 1973. , Teori Hukum Murni, DasarDasar Ilmu Hukum Normatif sebagai Ilmu Hukum Empirik-Deskriptif, Rimdi Press, Jakarta, 1995.

Hartono Widodo dan Judiantoro, Segi Hukum Penyelesaian Perselisihan Perburuhan, Rajawali, Jakarta, 1992.

Hart., H.L.A., "Konsep Hukum (The Concept Of Law)"., Nusa Media, 2009, Bandung.

Hasan, H.Engking Soewarman, Drs., "Metodologi Penelitian, Bandung, 1997. ., "Hukum Ketenaga Kerjaan Indonesia", PT. Raja Grafindo Persada, Cetakan 5, 2005, Jakarta.

H.D. van Wik/Willem Konijnenbelt, Hoofstukken van Administratief Recht (Utrecht : Uitgeverij Lemma B.V), 1995.

Imam Soepomo, Pengantar Hukum Perburuhan, Cetakan VII, Djambatan, Jakarta, 1985.

------------------, Hukum Perburuhan Bidang Hubungan Kerja, Djambatan, Jakarta, 1983.

Johny Ibrahim, Teori dan Metodologi Penelitian Hukum Normatif, Bayu Media Publishing Malang, Jawa Timur, 2006.

Maria Farida Indrati Soeprapto, Ilmu Perundang-Undangan Dasar dan Pembentukannya, Kanisius, Yogyakarta, 1998. 
Peter Mahmud Marzuki, Penelitian Hukum, Fajar Interpratama Offset, Jakarta, 2005.

Philipus M. Hadjon, Tentang Wewenang, Dalam Yuridika, nomor 5 dan 6, 1997

YW. Sunindhia dan Ninik Widiyanti, Masalah PHK dan Pemogokan, Bina Aksara, Jakarta, 1998.

\section{Perundang-Undangan}

UU No. 22 Tahun 1957 Tentang Penyelesaian Perselisihan Perburuhan.

UU No. 5 Tahun 1986 tentang Peradilan Tata Usaha Negara

UU No. 2 Tahun 2004 Tentang Penyelesaian

Hubungan Industrial 